\title{
Model of health service effectiveness in public health center based on dimensions and measuring indicators
}

\author{
Diding Sarifudin ${ }^{1 *}$, Suharyo Hadisaputro ${ }^{2}$, Agus Suwandono ${ }^{3}$
}

\author{
${ }^{1}$ Faculty of Medicine, Diponegoro University, Semarang, Indonesia \\ ${ }^{2}$ Department Health, Health Polytechnic, Semarang, Indonesia \\ ${ }^{3}$ Department of Public Health, Diponegoro University, Semarang, Indonesia
}

Received: 15 February 2021

Revised: 26 March 2021

Accepted: 30 March 2021

\author{
*Correspondence: \\ Dr. Diding Sarifudin, \\ E-mail: dings.crb@gmail.com
}

Copyright: () the author(s), publisher and licensee Medip Academy. This is an open-access article distributed under the terms of the Creative Commons Attribution Non-Commercial License, which permits unrestricted non-commercial

\begin{abstract}
Background: Moreover, the effectiveness of the outputs was measured and the effectiveness model was completely implemented to include the input and process. However, the results obtained from measuring the input and process element were not documented effectively, thereby, leading to the use of a perception proxy which is the measurement power on the effectiveness. This research was, therefore, conducted to produce a model of health service effectiveness in public health centers based on dimensions and measuring indicators.

Methods: This research was conducted quantitatively using a cross-sectional approach. The study population includes the employees of public health centers in Cirebon Regency out of which a sample of 212 respondents. The data obtained were subsequently analyzed using SmartPLS.

Results: The effectiveness was measured using 5 dimensions including inputs dimension which consists of utilization of budget and human resource ( 2 indicators), process dimension which consists of improvement efforts ( 2 indicators) and innovation efforts (4 indicators), and output dimension which consists of employee satisfaction ( 3 indicators) and program ( 1 indicator). Most of the respondents, represented by $60.3 \%$, stated that health services at the public health center were effective.

Conclusions: The health service effectiveness model in the public health center was formed by five dimensions and twelve measuring indicators.
\end{abstract}

Keywords: Effectiveness, Public health centers, Health services, Dimensions, Indicators

\section{INTRODUCTION}

The Healthy Indonesia Program is the Federal Government's commitment to Astana declaration, using the family approach. ${ }^{1}$ This family empowerment aims to produce healthy families, as measured by the Healthy Family Index (IKS), with 12 (twelve) indicators. This Healthy Family Index is in turn categorized into three, and these are healthy family (IKS $>0.800$ ), pre-healthy family (IKS 0.500-0.800), and unhealthy family (IKS <0.500). The target to be achieved is 0.800 or families in Indonesia are categorized as healthy families. ${ }^{1}$
Furthermore, the indicators on IKS, SPM (Minimum Service Standards), PKP (Public Health Center Performance Assessment), and other programs are a direct or indirect measure of the Public Health Center's progress. $^{2,3}$ These are called indirect measuring tools because the success involves other sectors or is a shared responsibility. Meanwhile, these are direct indicators due to the inseparability from the Public Health Center's role and responsibility to the community. This is because the Public Health Center is a health service facility organizing public and first-level individual health efforts, by prioritizing promotive as well as preventive efforts, to 
achieve the highest possible health degree within the respective community. ${ }^{4}$

Thus, the success of a Public Health Center measured through indicators is called the effectiveness of services, because effectiveness is an assessment made in relation to the achievements of individuals, groups, and organizations, or target attainment level, appropriate attainment of goals or selecting the right goals from aseries of alternatives or choice of means, and determining the choice of several other options..$^{5-7}$ In addition, effectiveness is also be interpreted as a measure of success in achieving predetermined goals. ${ }^{5,7}$ These indicators are therefore a suitable measure of the Public Health Center services' effectiveness.

Until October 2019, National Healthy Family Index based on evaluation results 8 amounted to 0.189 , meaning the families in Indonesia are majorly unhealthy. The West Java Province Healthy Family Index is 0.159 , indicating the families are categorized as unhealthy. ${ }^{10}$ Meanwhile, the Cirebon Regency's counterpart, based on the results of evaluation, is 0.189 , indicating families in the Regency are also unhealthy. ${ }^{11}$

In addition to IKS in Cirebon Regency, there are also several indicators on SPM and PKP currently below the target. The SPM indicator reached $66.7 \% 12$ in 2019, while the PKP indicator for mandatory efforts was low in 2018 $(35.8 \%){ }^{13}$

These low direct indicators for measuring the Public Health Center's success have resulted in ineffective health services at the center. According to another study, services at the Public Health Center have not been effective, including health services for pregnant women and babies at the Public Health Center in Kebondalem. ${ }^{14}$ For instance, the services provided by Gunawan Village Public Health Center to the community are ineffective, and the Health Social Security Agency (BPJS) Health program for inpatients has also not been effective. ${ }^{15,16}$

The organizational effectiveness assessment's multivariate design was formulated using systems theory, for analytical purposes. $^{5}$ Furthermore the organizational system comprises three basic components, input, process, and output. $^{5,7}$ Thus, distributing the criteria for effectiveness according to the organizational system gives efficiency seen from the use of budget and human resources planned from the activity's onset (input), making adaptation efforts in the form of improvement and development efforts, as well as innovative activities (process), to obtain employee satisfaction and productivity (performance) achieved is known from the program/activity indicators (output). ${ }^{5,7}$ Therefore, the dimensions of measuring the Public Health Center services's effectiveness comprises the use of budgets and human resources (input), improvement and innovation efforts (processes), employee satisfaction, as well as program/activity indicators (output).
The analysis of effectiveness mostly measures output or results, while the effectiveness model with a systems approach must measure the input and process elements as well. Currently, the results of input and process elements measurements are not well documented, due to poor recording and reporting, thus, the needs are not fulfilled. The measurement therefore uses a perception proxy, and perceptual studies have been conducted before. ${ }^{17-21}$ This is the power of perception in measuring Public Health Center services' effectiveness.

\section{Objectives}

This research aims to produce a health service effectiveness model in the Public Health Center, based on dimensions and measuring indicators.

\section{METHODS}

\section{Study design}

Non-experimental research (observational) with a cross sectional approach. ${ }^{22,23}$

\section{Location and time of study}

This research was conducted at Public Health Centers located in Cirebon Regency, West Java Province based on regional characteristics, namely: mountainous rural areas, lowland rural areas, coastal villages, mountainous urban areas, lowland cities and coastal cities. Each of these categories consists of 3 public health centers, bringing the total to 18 .

The observation period was carried out from April to July 2020 .

\section{Sampling technique}

The sample size uses a simple random sampling sample size calculation formula ${ }^{24}$ :

$$
\begin{aligned}
n=Z^{2} 1-\alpha \div 2 & \times P(1-P) N \div d^{2}(N-1)+Z^{2} 1-\alpha \\
& \div 2 P(1-P)
\end{aligned}
$$

where:

$\mathrm{n}=$ minimal sample size

$\mathrm{N}=$ population $=3207$ orang

$\mathrm{Z} 1-\alpha / 2=$ the standard normal distribution value at state $\alpha=$ $0,05=1,96$

$\mathrm{P}=$ the proportion of incidence in the population $=0,18$

$\mathrm{d}=$ the precision of the deviation from the population $=0,05$ 
Therefore, 212 people (respondent) were taken from public health centers with the criteria of rural and urban public health centers and based on the characteristics of the public health center areas, namely mountains, lowlands and beaches. Sampling of public health centers as a sample was carried out randomly from two criteria (rural and urban), with a ratio of one to one $(1: 1)$ based on the lowest number in each group. The smallest number was found in the urban criteria group in mountainous and coastal areas, namely 3 (three) public health centers each. So that the number of public health centers taken as a sample was 18 with the following details:

Rural public health center located in the mountains $=3$ units

Rural public health center located in the lowland $=3$ units

Rural public health center located in thebeach $=3$ units

Urban public health center located in the mountains $=3$ units

Urban public health center located in the lowland $=3$ units

Urban public health center located in the beach $=3$ units

After the public health center was selected, then from each public health center (18 units) a sample of public health center employees ( $n=212$ respondents) was taken simple random sampling and proportionally.

\section{Inclusion criteria}

Carry out health efforts. Minimum work period of 1 year. Carry out health effort tasks continuously for at least 1 year. Minimum education: D3 in Health education/study

\section{Exclusion criteria}

Carry out health effort tasks that are not equipped with a letter of assignment. In the last year, unable to carry out health efforts for more than 1 month for certain reasons. Have passed at least D3 in Health but do not have STR (Registration Certificate). Not willing to be the subject of research. Unable to attend the interview.

\section{Procedure and ethical clearance}

Written information was given by the Research Ethics Commission of the Faculty of Medicine, Gunung Jati University Cirebon for research involving living things which stated that this research was feasible to carry out.

By using Informed Consent. A process of delivering appropriate research information to respondents in order to obtain approval prior to conducting research.

\section{Analysis}

Using the PLS-SEM approach is based on shifting the analysis from the measurement of model parameter estimates to the measurement of the relevant model prediction25 262728 . The direction of the causality relationship from indicators to dimensions and variables or forming a construct using arrows $(\rightarrow)$

\section{RESULTS}

\section{Demographic data}

Table 1: Respondents frequency distribution.

\begin{tabular}{|lll|}
\hline Characteristic & Frequency & Percentage \\
\hline Sex & 47 & 21.5 \\
\hline Fale & 172 & 78.5 \\
\hline Total & 219 & 100.0 \\
\hline Education & & \\
\hline $\begin{array}{l}\text { D3 in healthy } \\
\text { education/study }\end{array}$ & 125 & 57.1 \\
\hline $\begin{array}{l}\text { D4 in health } \\
\text { education/study }\end{array}$ & 29 & 13.2 \\
\hline $\begin{array}{l}\text { S1 in healthy } \\
\text { education/study }\end{array}$ & 65 & 29.7 \\
\hline Total & 219 & 100.0 \\
\hline Regional specifications & & \\
\hline Rural & 102 & 46.6 \\
\hline Urban & 117 & 53.4 \\
\hline Total & 219 & 100.0 \\
\hline Age & \\
\hline Mean & 36.9 & \\
\hline SD & 8.2 \\
\hline Minimum & 22 \\
\hline Maximum & 54 \\
\hline Years of service & 11.4 \\
\hline Mean & 8.6 & \\
\hline SD & 1 & \\
\hline Minimum & 32.3 & \\
\hline Maximum & & \\
\hline & & \\
\hline
\end{tabular}

Most of the respondents $(78.5 \%)$ were female, and the education of the respondents was more than half $(57.1 \%)$ three health diplomas (D3 in health study). Respondents based on regional specifications turned out to be more than half $(53.4 \%)$ in urban areas.

The mean age of the respondents was 36.9 years with a standard deviation of 8.2 years, with the youngest being 22 years old and the longest being 54 years old. Meanwhile, the average working period is 11.4 years with a standard deviation of 8.6 years with the lowest working period is 1 year and the longest is 32.3 years. 
Table 2: Validity and reliability of dimensional indicators.

\begin{tabular}{|c|c|c|c|c|c|}
\hline Dimensions & $\begin{array}{l}\text { Indicator } \\
\text { Code }\end{array}$ & $\begin{array}{l}\text { Loading } \\
\text { Factor }\end{array}$ & $\begin{array}{l}\text { Cronbach's } \\
\text { Alpha }\end{array}$ & Composite Reliability & Description \\
\hline \multirow{2}{*}{$\begin{array}{l}\text { Utilization of } \\
\text { Budget and } \\
\text { Human } \\
\text { Resources }\end{array}$} & EAS1 & 0.823 & 0.763 & 0.856 & Supported by budget \\
\hline & EAS3 & 0.894 & & & Budget utilization \\
\hline \multirow{2}{*}{$\begin{array}{l}\text { Improvement } \\
\text { Efforts }\end{array}$} & EPe3 & 0.889 & 0.735 & 0.883 & Activity monitoring \\
\hline & EPe4 & 0.889 & & & Follow up monitoring \\
\hline \multirow{4}{*}{$\begin{array}{l}\text { Innovation } \\
\text { Efforts }\end{array}$} & EI2 & 0.756 & 0.884 & 0.928 & Innovation plan \\
\hline & EI3 & 0.893 & & & Implementation of innovation \\
\hline & EI4 & 0.908 & & & $\begin{array}{l}\text { Monitoring / evaluating the } \\
\text { implementation of innovation }\end{array}$ \\
\hline & EI5 & 0.852 & & & There are better results \\
\hline \multirow{3}{*}{$\begin{array}{l}\text { Employee } \\
\text { Satisfaction }\end{array}$} & EPu1 & 0.884 & 0.807 & 0.871 & Sense of secure \\
\hline & $\mathrm{EPu} 2$ & 0.878 & & & Comfortable feeling \\
\hline & EPu4 & 0.795 & & & Activity communication tool \\
\hline $\begin{array}{l}\text { Program } \\
\text { indicators }\end{array}$ & Average & 1.000 & 0.904 & 0.937 & Average indicator achievement \\
\hline
\end{tabular}

\section{Variable dimension and measuring indicators}

Table 3: Respondent's frequency distribution, based on the public health center services' effectiveness, and the respective dimensions.

\begin{tabular}{|c|c|c|}
\hline $\begin{array}{l}\text { Variable / } \\
\text { Dimension }\end{array}$ & Frequency & Percentage \\
\hline \multicolumn{3}{|l|}{ Effectiveness } \\
\hline Less effective & 15 & 6.8 \\
\hline Quite effective & 72 & 32.9 \\
\hline Effective & 132 & 60.3 \\
\hline Total & 219 & 100.0 \\
\hline \multicolumn{3}{|c|}{$\begin{array}{l}\text { Dimension of budget and human resources } \\
\text { utilization }\end{array}$} \\
\hline Good & 141 & 64.4 \\
\hline \multicolumn{3}{|c|}{ Dimension of improvement effort } \\
\hline Good & 162 & 74.0 \\
\hline \multicolumn{3}{|c|}{ Dimension of innovation effort } \\
\hline Good & 160 & 73.1 \\
\hline \multicolumn{3}{|c|}{ Dimension of employee satisfaction } \\
\hline Good & 166 & 75.8 \\
\hline \multicolumn{3}{|c|}{ Dimension of indicator } \\
\hline Good performance & 111 & 89.5 \\
\hline
\end{tabular}

The dimensions forming the variable of health service effectiveness at Public Health Centers comprised budget and human resource utilization (input), improvement and innovation efforts (process), employee satisfaction, as well as program/activity indicators (output).

Model estimation was also carried out, based on the Loading Factor coefficient, Cronbach's Alpha, and the Composite Reliability dimension indicator values. Subsequently, the dimension indicators with a Loading Factor value, Cronbach's Alpha, and Composite Reliability above 0.7 were selected, while indicators below 0.7 were dropped. Table 1 shows the results.

Table 3 shows the estimation and evaluation results of the model for measuring the health services effectiveness indicate all values (loading factor, Cronbach's alpha, and composite reliability) were $\geq 0.7$. Thus, the indicators were concluded to be ideal, namely valid and reliable, for measuring the dimensions formed.

\section{Measurement results}

Table 3 shows the measurement results of health service effectiveness variable at the Public Health Center and the respective dimensions.

According to Table 3, most $(60.3 \%)$ respondents stated health services at Public Health Service were already effective, and only $6.8 \%$ stated the opposite. The Public Health Center service effectiveness is a latent variable measured using the dimensions of budget and human resource utilization, improvement efforts, innovation efforts, employee satisfaction, as well as program indicators. Thus, the results show most respondents have a good opinion of the dimensions.

\section{DISCUSSION}

Based on the results, most respondents stated the Public Health Center's implementation of health services to the community is effective. The effectiveness was not only measured from the output, but also in a systemic manner, because the activity of providing health services is a unit (system) of input-process-output. As report by Gibson on systems theory considered organization as one of the interdependent elements. ${ }^{7}$ Good input and process result in good output as well, thus, systematic improvements were required to accelerate problem-solving. This is also in line 
with the study by 19 stating overcoming each factor systematically increases effectiveness and reduces threats to service sustainability. Similarly, a report by stated successful intervention characteristics specifically aimed at reducing health disparities include a systematic and intensive approach to providing effective health care. ${ }^{29}$

In this study, the effectiveness measures the system (input, process, and output) with a perception proxy, however, in cases where there is only a measurement on output effectiveness, this is not a problem. Steers stated this effectiveness is marked by the achievement of program indicator. ${ }^{5}$ In addition, indicators are often used as a measure of success. However, after the indicators for achieving each stage (input-process-output) have been formulated and determined as a measuring tool, the measurement of all stages becomes objective.

These results are reinforced by, stating health services in the Public Health Centers are already effective. ${ }^{30-33}$ However, the service effectiveness was determined with a different approach and was more focused on the services received by the community. This means the services are effective if the community's desires or needs are met. Conversely, this study determined the effectiveness thoroughly and systematically.

The health service effectiveness at the Public Health Center was improved by means of repairs or improvements in a system, therefore accelerating the center's achievement of goals.

\section{Limitations}

Affordable population is limited to only one district. There are some respondents who feel they do not have program / activity indicators because they are team members or implementers. This research was conducted during the Covid-19 pandemic, so there was limited contact time with respondents.

\section{CONCLUSION}

The health service effectiveness model in Public Health service comprised 5 (five) dimensions, utilization of budget and human resources (input), improvement and innovation efforts (process), employee satisfaction, and program indicators (output). Furthermore, 12 valid and reliable indicators were used to measure the dimensions formed. These were, input (budget and human resource utilization) (two indicators), process (improvement efforts (two indicators) and innovation efforts (four indicators), as well as output (employee satisfaction (three indicators) and program indicators (one indicator).

\section{ACKNOWLEDGEMENTS}

We are gratefull to the respondent (staff at the Public Health Center in Cirebon, West Java, Indonesia)
Funding: No funding sources

Conflict of interest: None declared

Ethical approval: The study was approved by the Institutional Ethics Committee

\section{REFERENCES}

1. Kemenkes RI. Peraturan Menteri Kesehatan nomor 39 tentang pedoman penyelenggaraan Program Indonesia Sehat dengan Pendekatan Keluarga. 2016;10.

2. Kemenkes RI. Peraturan Menteri Kesehatan Republik Indonesia Nomor 43 Tahun 2016. 2016;

3. Provinsi Jawa Barat DK. Pedoman Penilaian Kinerja Puskesmas. 2012.

4. Kemenkes RI. Peraturan Menteri Kesehatan nomor 75 tentang Pusat kesesehatan masyarakat. 2014: 155-162.

5. Steers R. Efektivitas Organisasi : kaidah perilaku. 1985.

6. Rifa'i F. Manajemen Organisasi. Vol. 53, Journal of Chemical Information and Modeling. 2013;16891699.

7. Gibson, James L, Ivancevich, John M and Donnelly JH. Organisasi - Perilaku, Struktur, Proses. 1996.

8. Kementeri Kesehatan RI, Direktur Jenderal Pelayanan Kesehatan. Arah dan Kebijakan Program Pembinaan Pelayanan Kesehatan Tahun 2020-2024. 2019.

9. Kementeri RI. Aplikasi Keluarga Sehat Versi 2.0. 2019.

10. Kementeri RI. Jabar pemanfaatan hasil PIS-PK dalam akselerasi SPM. 2019.

11. Dinas Kesehatan Propinsi Jawa Barat. Strategi Intervensi Program PISPK. 2019

12. Cirebon K, Kesehatan D. Profil Kesehatan Kabupaten Cirebon 2019. 2019.

13. Cirebon K, Kesehatan D. Laporan tahunan bidang pelayanan kesehatan Tahun 2019. 2019.

14. Sari FY. Efektivitas pelayanan kesehatan bagi ibu hamil dan bayi miskin di puskesmas Kebondalem Kecamatan Bangorejo Kabupaten Banyuwangi. 2014.

15. Konli S. Pelayanan kesehatan masyarakat DI Puskesmas Desa Gunawan Kecamatan Sesayap Kabupaten Tana Tidung. 2014;21:1925-36.

16. Fitriani AN, Irawan B, Prakoso CT. Efektivitas pelayanan rawat inap bagi peserta BPJS Kesehatan di Puskesmas Lempake Kota Samarinda. 2019;81:9479-93.

17. Cichocki P IC. Organization design: a guide to building effective organizations. The SAGE Glossary of the Social and Behavioral Sciences. 2012.

18. UNICEF W. Primary health care: transforming vision into action Operational Framework Draft for consultation. 2018;55.

19. Wakerman J, Humphreys, John S. Wells, Robert. Kuipers P. Features of effective primary health care models in rural and remote Australia: a case-study analysis. Model Care. 2009. 
20. Budrevičiūtė A, Kalèdienè R, Petrauskienė J. Priorities in effective management of primary health care institutions in Lithuania: Perspectives of managers of public and private primary health care institutions. PLoS One. 2018;13(12):1-17.

21. Poulton BC, West MA. The determinants of effectiveness in primary health care teams. Journal of Interprofessional Care. 2009;13:7-18.

22. Creswell JW. Research design: qualitative, quantitative, and mixed methods approaches. SAGE Publications Asia-Pacific Pte. Ltd. 4th edition. 2014.

23. Sugiyono. Metode penelitian kuantitatif kualitatif dan r\&d. Penerbit Alfabeta Bandung. 2010;334.

24. Lemeslow S. Besar sampel dalam penelitian kesehatan. Gadjah Mada University Press, Yogyakarta. 1997.

25. Hariyono S. Metode SEM Untuk Penelitian Manajemen AMOS LiSREL PLS. Pt Ipu. 2016;1473.

26. Narimawati U, Sarwono J. Structural Equation Modelling (SEM); Berbasis Kovarian dengan LISREL dan AMOS untuk Riset Skripsi, Tesis dan Disertasi [Internet]. Selemba Empat. 2017;246. http://www.jonathansarwono.info/sem/konsep_dasar __sem.htm. Last accessed on

27. Ghozali I. Structural Equation Modeling, Metode alternatif dengan Partial Least Square (PLS). Badan Penerbit Undip. 2014;Xvi:410.

28. Sholihin M, Ratmono D. Analisis SEM-PLS dengan WarpPLS 3.0, untuk hubungan nonlinier dalam penelitian sosial dan bisnis. Yogyakarta: Andi Offset. 2013;vi:290.

29. Arblaster L, Lambert M, Entwistle V, Forster M, Fullerton D, Sheldon T, et al. A Systematic Review of the Effectiveness of Health Service Interventions Aimed at Reducing Inequalities in Health. Journal of Health Services Research \& Policy. 1996;1:93-103.

30. Juliansyah E. Efektivitas Pelayanan Kesehatan Di Puskesmas [Internet]. JIANA ( Jurnal Ilmu Administrasi Negara ). 2013;12:40-50.

31. Prakoso SB. Efektivitas Pelayanan Kesehatan Bpjs Di Puskesmas Kecamatan Batang. Economics Development Analysis Journal. 2017;4:73-81.

32. Sari NHF dan SM dan S. Efektivitas Pelayanan Kesehatan Pasien Bpjs (Badan Penyelenggara Jaminan Sosial) Di Puskesmas (Studi Kasus Di Puskesmas Dinoyo Kota Malang). Respon Publik. 2019;13:113-21.

33. Indah AT, Rasyid H Al, Erri D. Efektivitas Pelayanan Prima Bagian Poli Pada Puskesmas Pondok Aren Tangerang. Journal of Chemical Information and Modeling. 2019; 53:1689-99.

Cite this article as: Sarifudin D, Hadisaputro S, Suwandono A. Model of health service effectiveness in public health center based on dimensions and measuring indicators. Int J Community Med Public Health 2021;8:2206-11. 